\title{
PENENTUAN PARAMETER PENGELASAN RANGKA UTAMA SEPEDA MOTOR MATIC BAGIAN DEPAN MENGGUNAKAN LAS MIG OTOMATIS (PANASONIC TM-1400G3)
}

\author{
Yusril Irwan dan Gatot Pamungkas \\ Jurusan Teknik Mesin, Fakultas Teknologi Industri, \\ Institut Teknologi Nasional Bandung, 082129147101 \\ e-mail: yusrilirwan1@gmail.com
}

\begin{abstract}
Main frame welding at the front automatic motorcycle of PT. XXX is the stage of (trial production). The welding machine is Panasonic TM-1400G3 MIG automatic welding machine with 75\% Argon and 25\% Ar-CO2. Main frame material low carbon steel STAM 390G. To obtain the welding results in accordance with the standards specified by the client, weld testing parameters are varied for each test, which are ampere and voltage. The constant welding parameters in this research are travel speed, gas flow, welding direction, tip distance to workpiece, torch angle and welding angle. All test results are inspected visually and dimensionally, if passed, it will be followed by inspection of macro structure analysis. The results measured on the macro structure analysis ar : penetration (a1), penetration (a2), bead welding, throuth, leg length and crown with standard measurement values determined by the client PT.XXX. The welding results $(\mathrm{OK})$ in the macro structure analysis measurement are defined as reference parameters for mass production. The best parameters for main frame welding are vertical position down (3G) with 170 Ampere current and 20 Volt voltages, and for horizontal position (2G) with 180 ampere current parameters and 17 Volt voltages.
\end{abstract}

Keyword: Main frame Welding, MIG Automatic, weld testing parameters

\section{PENDAHULUAN}

PT. XXX adalah perusahaan yang memproduksi komponen otomotif roda dua dan roda empat, salah satu komponen otomotif roda dua yang dibuat adalah rangka utama (main frame) sepeda motor matik. Rangka utama (main frame) sepeda motor matik merupakan komponen yang dibuat menggunakan pipa baja karbon rendah STAM390G dan penyambungan menggunakan proses pengelasan. Metode pengelasan yang digunakan adalah MIG (Metal Inert Gas) otomatis dengan gas pelindung campuran antara 75\% Argon dan 25\% Karbondioksida (Ar- $\left.\mathrm{CO}_{2}\right)$, menggunakan robot las Panasonic TM-1400G3. Pengelasan rangka utama (main frame) sepeda motor matik dilakukan pada meja pemegang (jig) untuk mencegah distorsi akibat panas dari proses pengelasan yang menyebabkan perubahan bentuk material.

Saat ini produksi rangka utama (main frame) sepeda motor matik di PT. XXX adalah tahap produksi percobaan (trial production), yaitu tahap mencari proses produksi yang terbaik untuk mendapatkan produk yang sesuai dengan spesifikasi yang ditentukan oleh klien pemesan produk, salah satu produksi percobaan yang dilakukan adalah mencari parameter pengelasan yang terbaik. Parameter pengelasan yang diatur adalah ampere, voltage, travel speed, gas flow dan sudut pengelasan. Pencarian parameter pengelasan dilakukan dengan melakukan percobaan pengelasan dengan parameter-parameter yang bervariasi, setiap produk hasil pengelasan diinspeksi untuk mengetahui kualitasnya apakah masuk kedalam spesifikasi atau tidak.

Inspeksi kualitas hasil pengelasan terdiri dari inspeksi visual dan pengujian struktur makro hasil pengelasan sesuai dengan standar inspeksi hasil pengelasan yang ditentukan oleh klien. Inspeksi visual dilakukan untuk memastikan tidak ada cacat pengelasan berupa porositas pada permukaan hasil pengelasan dan mengukur lebar bead welding hasil pengelasan yang sesuai dengan standar [1]. Pengujian struktur makro material hasil pengelasan dilakukan untuk mengetahui penetrasi, lebar bead welding, throuth, leg length, undercut, crown, dan porositas pada logam induk yang ditentukan pada standar inspeksi hasil pengelasan. Setelah mendapatkan parameter pengelasan yang sesuai maka parameter tersebut akan digunakan sebagai acuan pengelasan pada produksi massal. 


\section{METODE PENELITIAN}

\section{Rangka Utama Sepeda Motor Matik Bagian Depan}

Rangka utama sepeda motor matik dapat dilihat pada Gambar 1, gambar yang diberi lingkaran berwarna merah adalah yaitu rangka utama bagian depan (main frame).
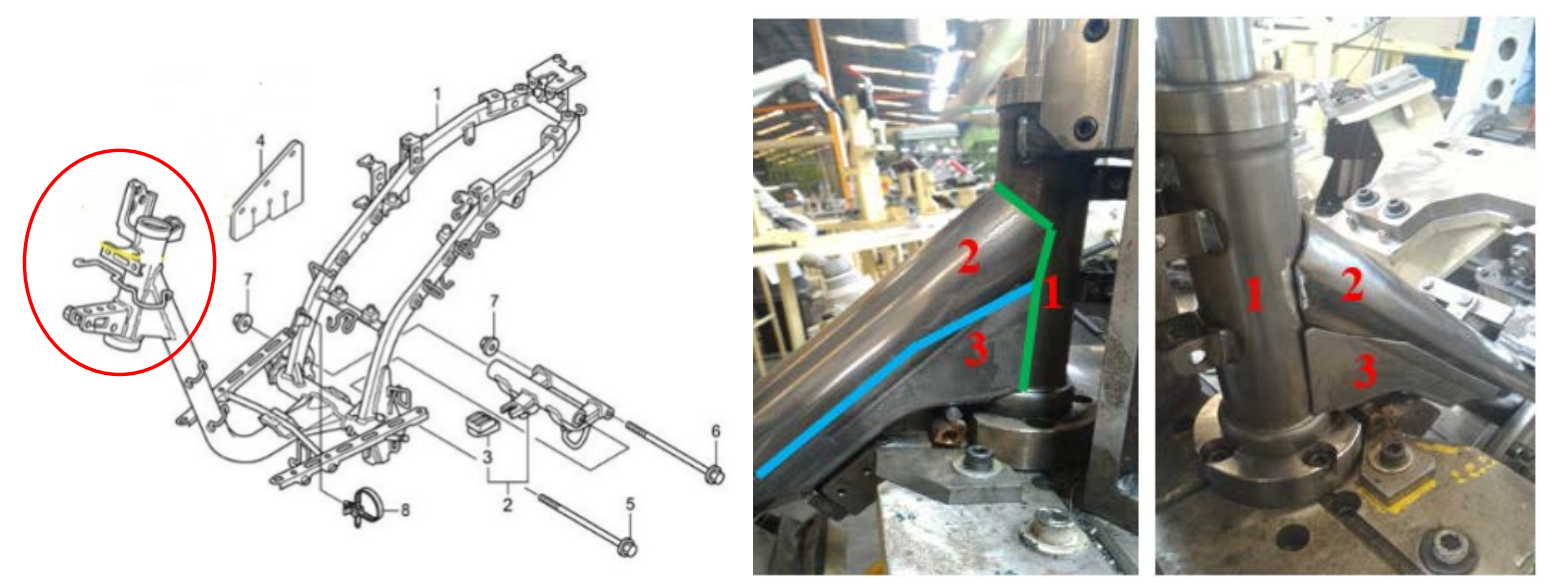

Gambar 1. Rangka utama sepeda motor matik

Rangka utama sepeda motor matik bagian depan terdiri dari 3 komponen yang digabungkan dengan proses pengelasan. Komponen yang akan dilas diletakkan pada jig, sehingga proses pengelasan dilakukan sesuai dengan posisi komponen tersebut. Posisi pengelasan yang digunakan adalah posisi pengelasan horizontal 2G dan vertikal 3G. Garis hijau pada Gambar 1, menunjukkan daerah yang akan dilakukan proses pengelasan dengan posisi vertikal 3G dan garis biru menunjukkan daerah yang akan dilakukan proses pengelasan dengan posisi horizontal 2G [2].

Material yang digunakan untuk rangka sepeda motor matik bagian depan dalam penelitian ini adalah material baja karbon rendah STAM 390 G dengan standar JIS G 3472. Material STAM $390 \mathrm{G}$ termasuk kedalam golongan baja karbon rendah karena memiliki presentase kadar karbon maksimum $0,25 \%$, baja digolongkan menjadi baja karbon rendah apabila memiliki presentase kadar karbon 0,005\% sampai 0,3\%. Batasan komposisi kimia dan sifat mekanik dari material STAM 390 G ditetapkan dalam standar JIS G 3472.

\section{Diagram Alir Penelitian}

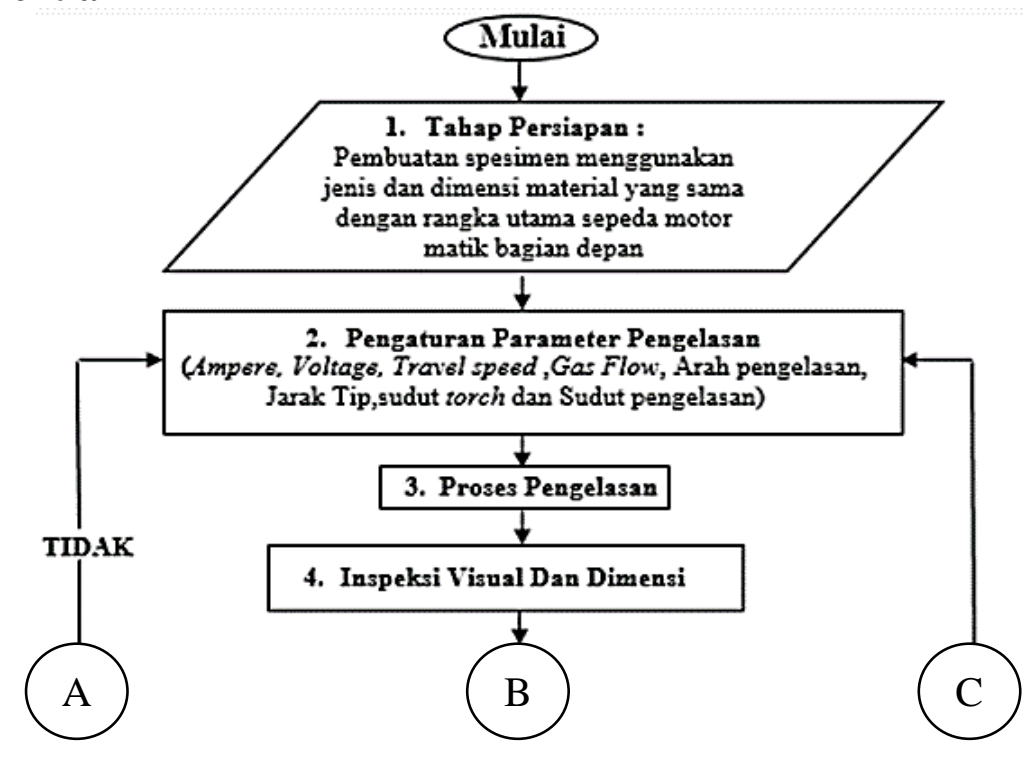

Gambar 1. Diagram alir penelitian 


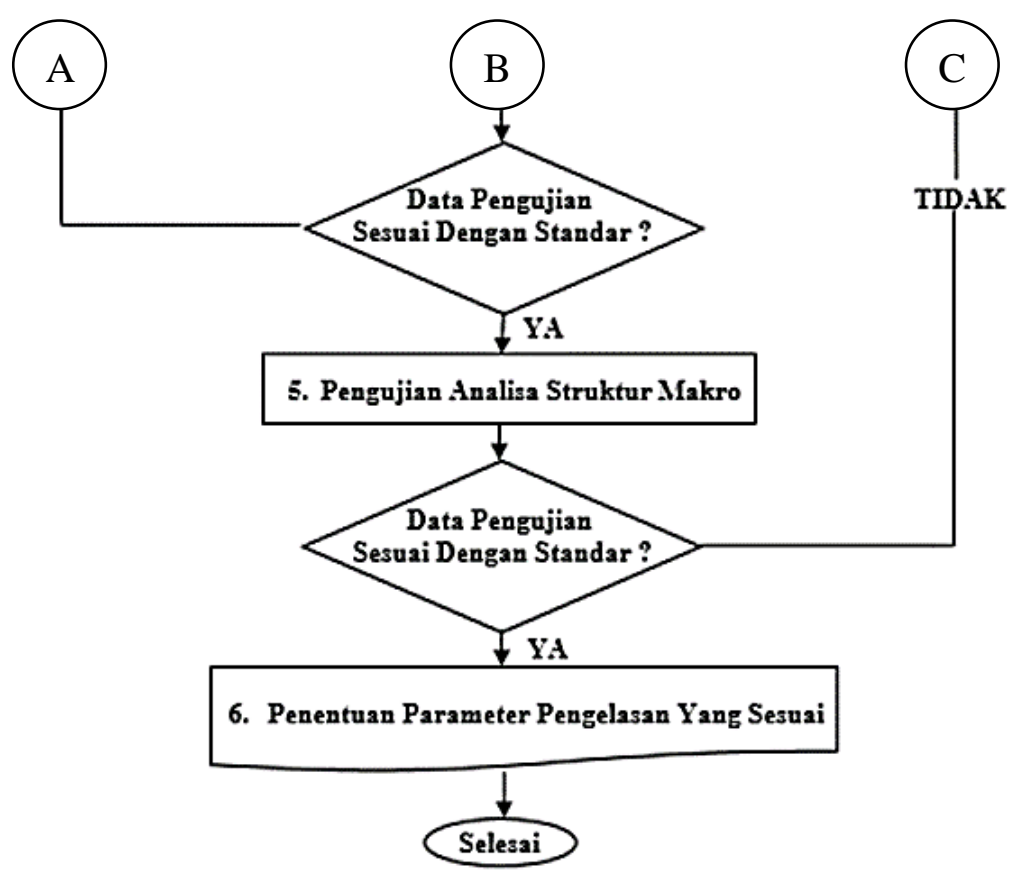

Lanjutan Gambar 1. Diagram alir penelitian

\section{Tahap Persiapan}

Tahap ini adalah tahap pembuatan spesimen menggunakan jenis dan dimensi material yang sama dengan rangka utama sepeda motor matik bagian depan. Spesimen yang dibuat dibagi menjadi 2 berdasarkan posisi pengelelasannya, berikut adalah spesimen yang dibuat pada penelitian ini:

\section{Spesimen Pipe Head}

Spesimen ini dibuat untuk mewakili pengelasan antara pipe head $(3,5 \mathrm{~mm})$, pipe main $(2,3$ $\mathrm{mm})$, dan gusset pipe head $(2,3 \mathrm{~mm})$ dengan posisi pengelasan vertikal $3 \mathrm{G}$ dan jenis sambungan flare lap joint. Untuk menyambungkan kedua material sebelum dilakukan pengelasan permanen adalah dengan cara las cantum (tack weld) yang diberi lingkaran merah pada gambar.

\section{Spesimen Pipe Main}

Spesimen ini dibuat untuk mewakili pengelasan antara pipe main $(2,3 \mathrm{~mm})$ dengan gusset pipe head (2,3 mm) dengan posisi pengelasan horizontal $2 \mathrm{G}$ dan jenis sambungan flare lap joint.
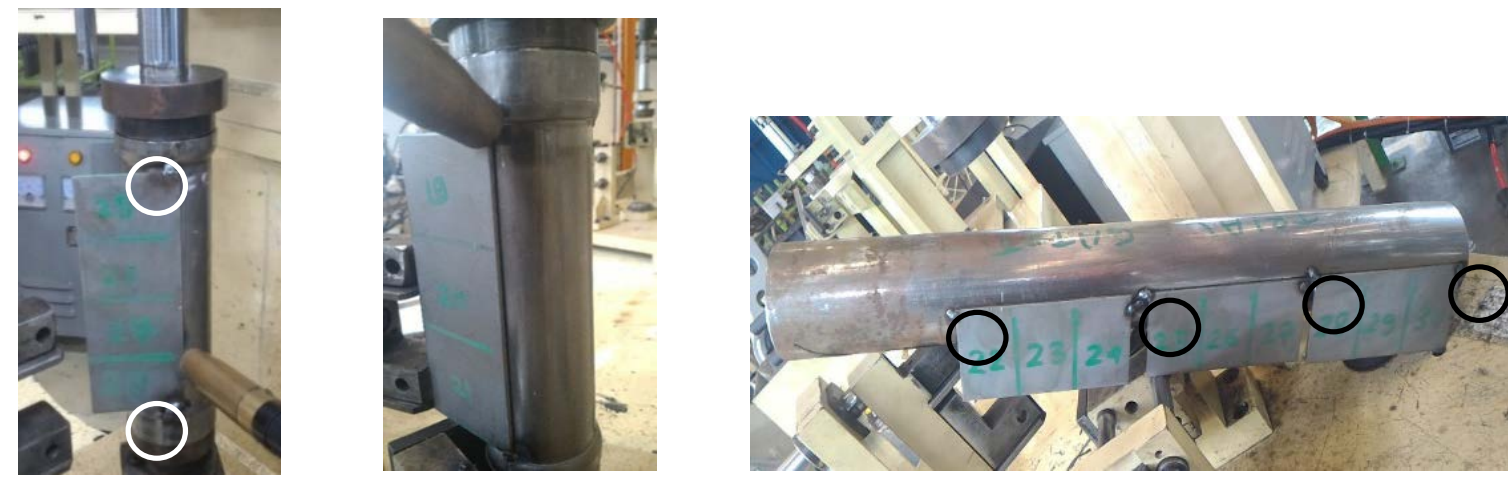

Gambar 3. Spesimen head dan pipe pipe main

\section{Pengaturan Parameter Pengelasan}

1. Parameter pengelasan yang dibuat konstan

Travel Speed $\quad=0,8$ meter $/$ menit 


$\begin{array}{ll}\text { Gas Flow } & =10 \text { liter/menit } \\ \text { Posisi Pengelasan } & =\text { Vertikal Kebawah (3G), Horizontal (2G) } \\ \text { Arah Pengelasan } & =\text { Maju (untuk posisi 3G), Mundur (untuk posisi 2G) } \\ \text { Sudut Torch } & =10^{\circ} \\ \text { Jarak Tip } & =10 \mathrm{~mm} \\ \text { Sudut Pengalasan } & =70^{\circ} \\ \text { Polaritas Pengelasan } & =\text { DCEP } \\ \text { Wire Feed } & =\text { Ditentukan Otomatis Oleh Mesin Las }\end{array}$

2. Parameter pengelasan yang dibuat bervariasi

Parameter pengelasan yang dibuat bervariasi pada penelitian ini adalah arus listrik pengelasan (Ampere) dimulai dari 100 sampai 190 ampere, dan dengan tegangan listrik pengelasan (Voltage) yang digunakan adalah 15, 17, dan 20 volt untuk setiap arus listrik pengelasan yang digunakan.

\section{Proses Pengelasan}

Proses pengelasan pada penelitian ini dibuat sama dengan proses pengelasan sesungguhnya pada produksi massal nantinya, proses pengelasan dilakukan dimeja kerja dan benda kerja diletakkan pada JIG.

1. Proses pengelasan spesimen pipe head

Pengelasan dengan arah vertical downhill dilakukan pada spesimen pipe head.
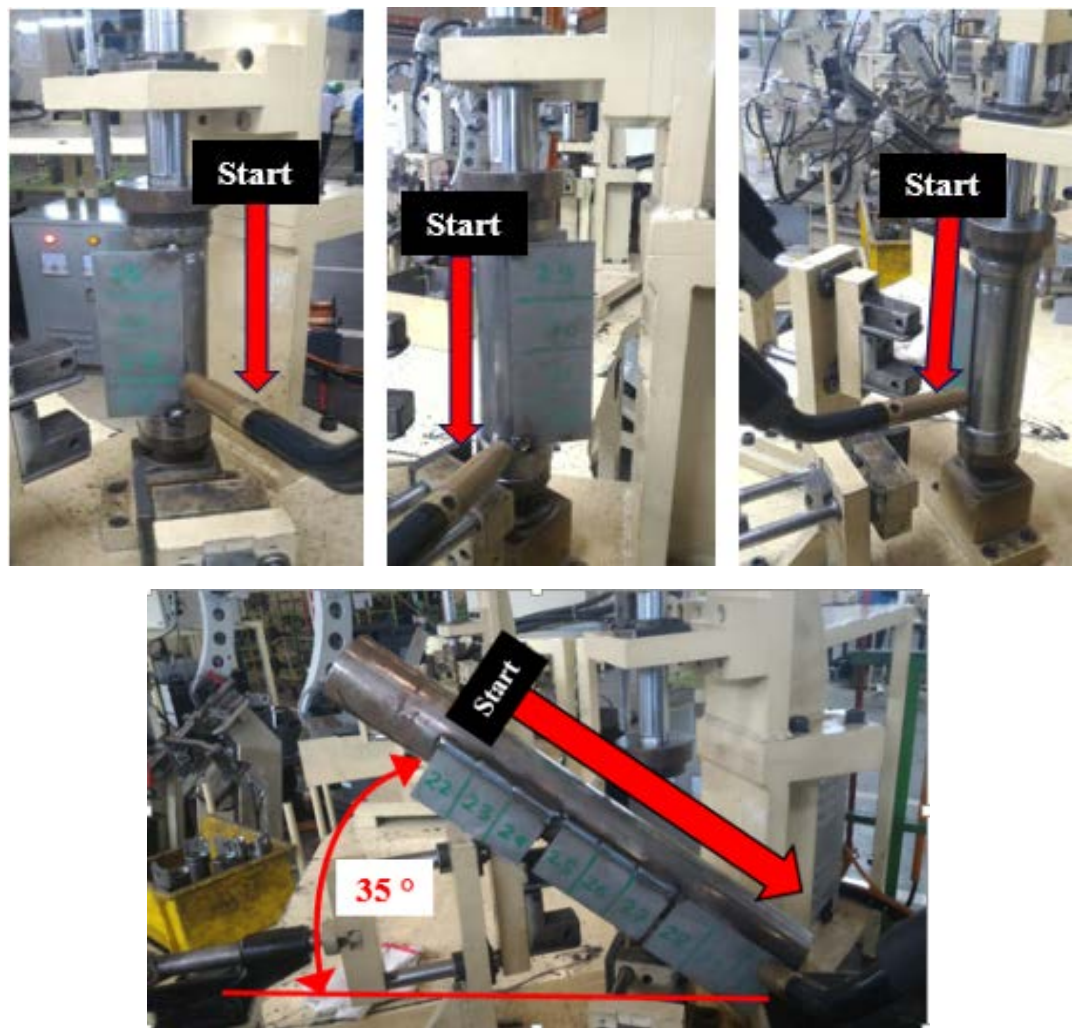

Gambar 4. Proses pengelasan spesimen pipe head dan proses pengelasan

\section{Proses pengelasan spesimen pipe main}

Pengelasan dengan arah horizontal dilakukan pada spesimen pipe main. Sudut kemiringan spesimen dibuat sama dengan kondisi sesungguhnya ketika benda kerja diletakkan pada JIG, yaitu sebesar 35, seperti pada Gambar 4. 
Kawat elektroda yang digunakan untuk pengelasan MIG otomatis dengan robot las Panasonic TM-1400G3 ini adalah kawat elektroda baja AWS A5.18 ER70S-6 diameter 1,2 mm dengan merek dagang ENKA [6].
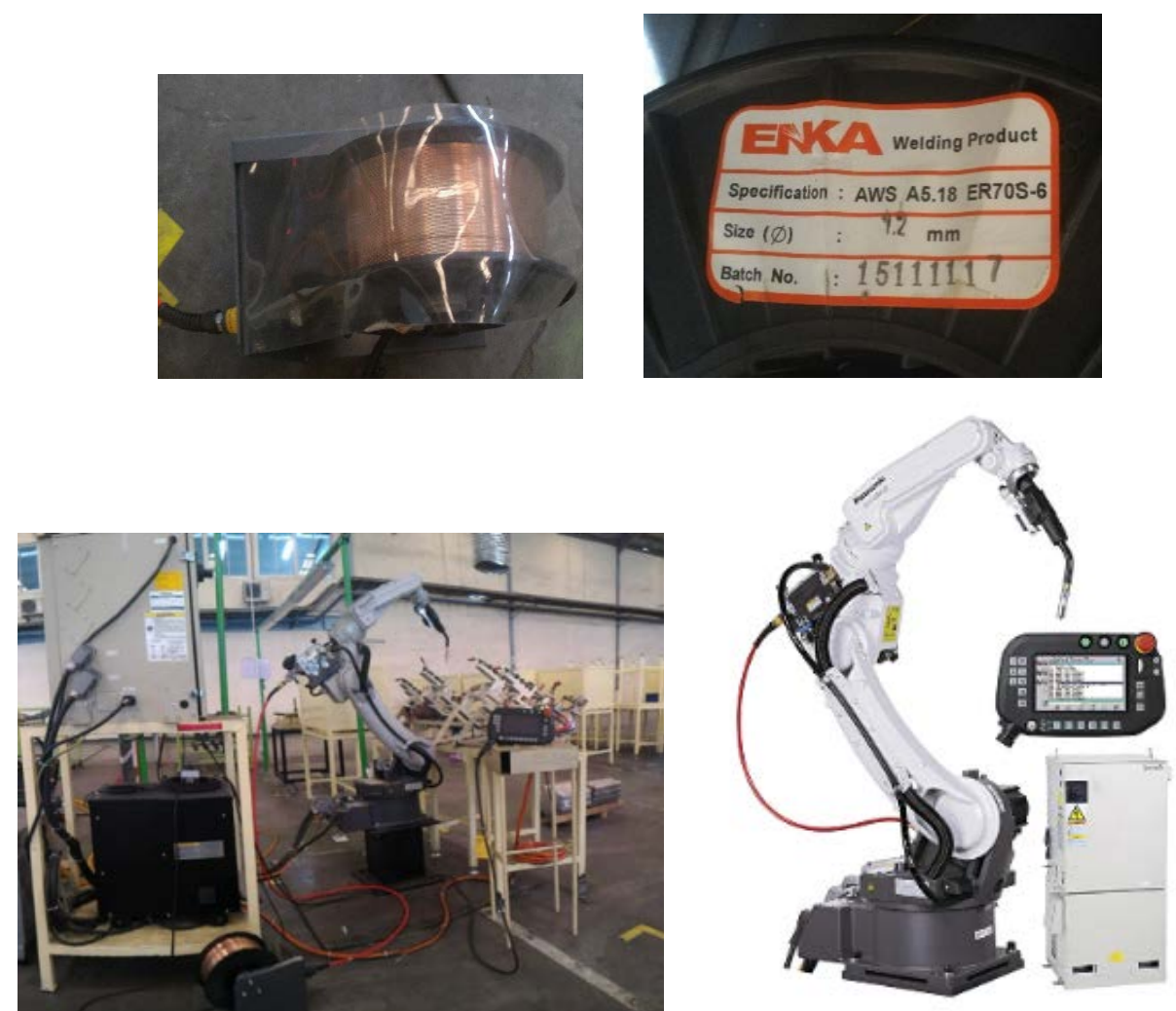

Gambar 5. Elektroda dan robot las mig otomatis Panasonic

\section{Inspeksi Visual dan Dimensi}

Pengecekan visual dan dimensi hasil pengelasan dilakukan untuk mengetahui dimensi bead welding dan melihat apakah ada cacat pengelasan pada permukaan hasil lasan. Standar inspeksi visual dan dimensi pada daerah hasil pengelasan adalah sebagai berikut:

a. Visual hasil pengelasan tidak diizinkan ada porositas pada permukaan hasil lasan, apabila ada porositas pada permukaan daerah pengelasan maka hasil lasan dianggap gagal (reject)

b. Visual manik las hasil pengelasan pada satu tarikan pengelasan harus seragam atau sama, apabila manik las tidak seragam dan cenderung berubah-ubah maka hasil lasan dianggap gagal (reject).

c. Penetrasi logam las (weld metal) tidak diizinkan tembus ke dasar material atau dasar base metal, penetrasi weld metal pengelasan yang tembus ke dasar material menyebabkan material bolong. Pada Gambar 6 diperlihatkan gambar yang diberi lingkaran merah merupakan penetrasi weld metal yang tidak tembus ke dasar material.

Dimensi lebar minimum bead welding yang diizinkan adalah $6 \mathrm{~mm}$, standar ini ditentukan oleh PT. XXX. Pengukuran dilakukan manual menggunakan jarak sorong (Vernier Caliper). Standar pengukuran: Bead Welding $<6 \mathrm{~mm}=$ Gagal $(N O T$ GO) dan jika Bead Welding $\geq 6 \mathrm{~mm}=$ Lanjut ke uji makro.

\section{Pengujian Analisis Struktur Makro}

Pengujian analisis struktur makro dilakukan untuk mengetahui ukuran-ukuran dari hasil pengelasan, yaitu: penetrasi, lebar bead welding, throuth, leg length, undercut, crown dan porositas. Pengujian analisis struktur makro dilakukan apabila hasil pengelasan memiliki lebar bead welding 
lebih besar atau sama dengan $6 \mathrm{~mm}$. Pengukuran daerah pengelasan dilakukan secara langsung menggunakan mikroskop digital, sehingga ukuran daerah pengelasan akan langsung dapat terbaca pada hasil foto makro. Standar ukuran hasil pengelasan ditentukan oleh klien dari PT. XXX.
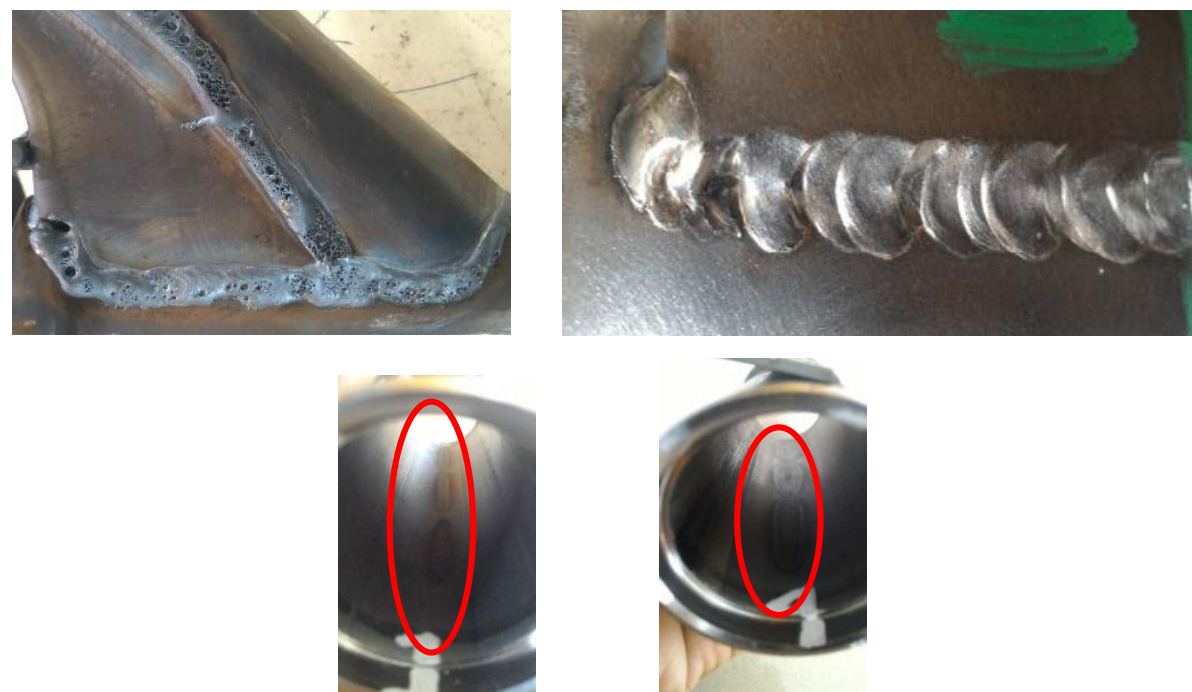

Gambar 6. Porositas, manik las dan penetrasi pada permukaan hasil lasan

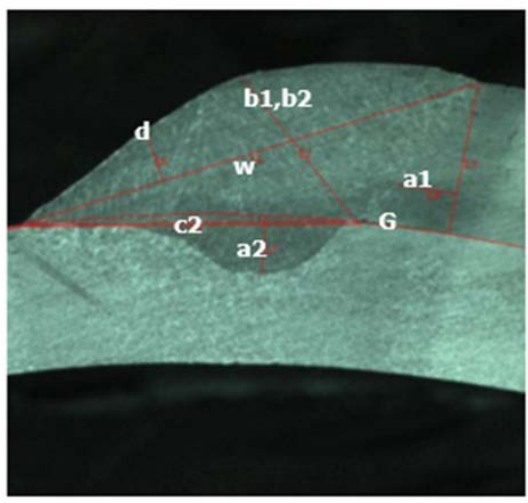

\begin{tabular}{|c|c|c|c|c|c|c|}
\hline \multirow{2}{*}{ Sample } & \multicolumn{2}{|c|}{ Point check } & $\left|\begin{array}{l}\text { Ref.std } \\
(\mathrm{mm})\end{array}\right|$ & \begin{tabular}{|l} 
Actual \\
$(\mathrm{mm})$
\end{tabular} & OK/NG & \multirow[t]{2}{*}{ Result } \\
\hline & Penetrasi & a1 & & & OK & \\
\hline \multirow{6}{*}{-} & $(\min )$ & $\mathrm{a} 2$ & 0,23 & 0,87 & OK & \multirow{10}{*}{ OK } \\
\hline & Throuth & b1 & 2,30 & & & \\
\hline & $(\min )$ & b2 & 2,30 & 2,77 & OK & \\
\hline & Leg Length & $\mathrm{c} 1$ & - & - & - & \\
\hline & $(\min )$ & $\mathrm{c} 2$ & 2,76 & 4,97 & OK & \\
\hline & $\begin{array}{l}\text { Bead width } \\
\text { (min) }\end{array}$ & w & 6,00 & 7,11 & OK & \\
\hline \multirow{6}{*}{$\mid \begin{array}{l}A=160 \\
V=17\end{array}$} & \multicolumn{2}{|c|}{ Undercut (Max) } & 0,46 & 0,00 & OK & \\
\hline & $\begin{array}{l}\text { Crown } \\
\text { (min) }\end{array}$ & d & 0,00 & 0,81 & OK & \\
\hline & \multicolumn{2}{|c|}{ Gap (max) } & 1,00 & 0,00 & OK & \\
\hline & \multicolumn{2}{|c|}{ Porosity (max) } & 0,00 & 0,00 & OK & \\
\hline & t.material & t1 & 2,30 & & & \\
\hline & $(\mathrm{mm})$ & t2 & 2,30 & & & \\
\hline
\end{tabular}

Gambar 7. Hasil pengujian analisis struktur makro material
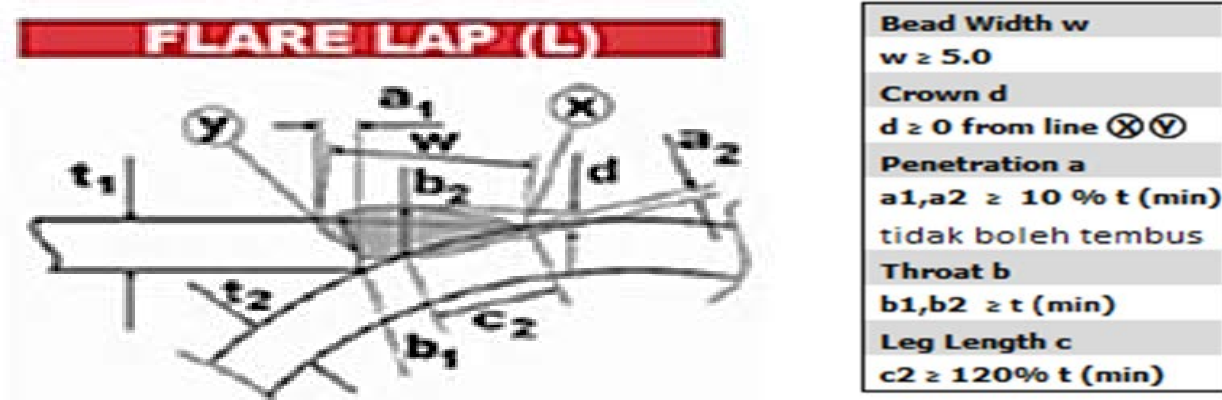

Gambar 8. Standar inspeksi hasil pengelasan dari Klien PT. XXX

\section{Penentuan Parameter Pengelasan yang Sesuai}

Parameter pengelasan yang dinyatakan baik atau sesuai apabila memiliki nilai hasil pengelasan per sub variabel diatas rata-rata (mean) dan yang memiliki nilai sub variabel lulus (OK) terbanyak untuk setiap sampel hasil pengelasan. Nilai per sub variabel yang dimaksud adalah sebagai berikut: penetrasi pada material 1 (a1), penetrasi pada material 2 (a2), lebar bead welding (W), throuth (b1, b2), leg length (c1, c2) dan crown (d). 
Setelah diketahui hasil dari setiap sub variabel pengelasan yang berupa keputusan gagal (NG) dan lulus (OK), pengujian selanjutnya adalah menilai jumlah keputusan lulus (OK) terbanyak untuk setiap sampel hasil pengelasan. Sampel hasil pengelasan yang tidak memiliki keputusan gagal (NG) atau hasil keputusannya lulus (OK) semua, maka akan ditetapkan sebagai parameter pengelasan yang sesuai atau parameter pengelasan yang akan digunakan untuk produksi massal nantinya.

\section{HASIL DAN PEMBAHASAN \\ Hasil Inspeksi Visual dan Dimensi}

Dari hasil pengujian parameter pengelasan untuk spesimen pipe head dan pipe main tidak ditemukan adanya cacat pengelasan pada permukaan pengelasan, sehingga semua spesimen dilanjutkan untuk diuji dimensi lebar bead welding.

Tabel 1. Hasil Inspeksi Dimensi Spesimen Pipe Head

\begin{tabular}{|c|c|c|c|c|c|}
\hline $\begin{array}{l}\text { Nomor } \\
\text { Sampel }\end{array}$ & $\begin{array}{c}\text { Arus } \\
\text { Listrik } \\
\text { [Ampere] }\end{array}$ & $\begin{array}{c}\text { Tegangan } \\
\text { Listrik } \\
\text { [Volt] }\end{array}$ & $\begin{array}{c}\text { Lebar } \\
\text { Bead } \\
\text { Welding } \\
\text { Minimum } \\
\text { [mm] }\end{array}$ & $\begin{array}{c}\text { Lebar } \\
\text { Bead } \\
\text { Welding } \\
\text { Aktual } \\
\text { [mm] }\end{array}$ & $\begin{array}{c}\text { Hasil } \\
\text { [OK } \\
/ \\
\text { NG] }\end{array}$ \\
\hline 1 & \multirow{3}{*}{100} & 15 & 6,00 & 4,00 & NG \\
\hline 2 & & 17 & 6,00 & 4,47 & NG \\
\hline 3 & & 20 & 6,00 & 4,50 & NG \\
\hline 4 & \multirow{3}{*}{110} & 15 & 6,00 & 4,85 & NG \\
\hline 5 & & 17 & 6,00 & 4,90 & NG \\
\hline 6 & & 20 & 6,00 & 5,40 & NG \\
\hline 7 & \multirow{3}{*}{120} & 15 & 6,00 & 4,90 & NG \\
\hline 8 & & 17 & 6,00 & 5,00 & NG \\
\hline 9 & & 20 & 6,00 & 5,30 & NG \\
\hline 10 & \multirow{3}{*}{130} & 15 & 6,00 & 5,50 & NG \\
\hline 11 & & 17 & 6,00 & 6,10 & OK \\
\hline 12 & & 20 & 6,00 & 6,50 & OK \\
\hline 13 & \multirow{3}{*}{140} & 15 & 6,00 & 5,70 & NG \\
\hline 14 & & 17 & 6,00 & 6,30 & OK \\
\hline 15 & & 20 & 6,00 & 7,60 & OK \\
\hline 16 & \multirow{3}{*}{150} & 15 & 6,00 & 6,90 & OK \\
\hline 17 & & 17 & 6,00 & 6,20 & OK \\
\hline 18 & & 20 & 6,00 & 7,60 & OK \\
\hline 19 & \multirow{3}{*}{160} & 15 & 6,00 & 6,60 & OK \\
\hline 20 & & 17 & 6,00 & 6,80 & OK \\
\hline 21 & & 20 & 6,00 & 7,90 & OK \\
\hline 22 & \multirow{3}{*}{170} & 15 & 6,00 & 6,90 & OK \\
\hline 23 & & 17 & 6,00 & 7,75 & OK \\
\hline 24 & & 20 & 6,00 & 8,65 & OK \\
\hline 25 & \multirow{3}{*}{180} & 15 & 6,00 & 7,40 & OK \\
\hline 26 & & 17 & 6,00 & 7,40 & OK \\
\hline 27 & & 20 & 6,00 & 9,00 & OK \\
\hline 28 & \multirow{2}{*}{190} & 15 & 6,00 & 7,72 & OK \\
\hline 29 & & 17 & 6,00 & 8,25 & OK \\
\hline
\end{tabular}

Tabel 2. Hasil Inspeksi Dimensi Spesimen Pipe Main

\begin{tabular}{|c|c|c|c|c|c|}
\hline $\begin{array}{l}\text { Nomor } \\
\text { Sampel }\end{array}$ & $\begin{array}{c}\text { Arus } \\
\text { Listrik } \\
\text { [Ampere] }\end{array}$ & $\begin{array}{c}\text { Tegangan } \\
\text { Listrik } \\
\text { [Volt] }\end{array}$ & $\begin{array}{c}\text { Lebar } \\
\text { Bead } \\
\text { Welding } \\
\text { Minimum } \\
\text { [mm] }\end{array}$ & $\begin{array}{c}\text { Lebar } \\
\text { Bead } \\
\text { Welding } \\
\text { Aktual } \\
\text { [mm] }\end{array}$ & $\begin{array}{c}\text { Hasil } \\
\text { [OK } \\
/ \\
\text { NG] }\end{array}$ \\
\hline 1 & \multirow{3}{*}{100} & 15 & 6,00 & 3,90 & NG \\
\hline 2 & & 17 & 6,00 & 4,20 & NG \\
\hline 3 & & 20 & 6,00 & 5,30 & NG \\
\hline 4 & \multirow{3}{*}{110} & 15 & 6,00 & 4,20 & NG \\
\hline 5 & & 17 & 6,00 & 4,40 & NG \\
\hline 6 & & 20 & 6,00 & 4,90 & NG \\
\hline 7 & \multirow{3}{*}{120} & 15 & 6,00 & 4,25 & NG \\
\hline 8 & & 17 & 6,00 & 4,60 & NG \\
\hline 9 & & 20 & 6,00 & 5,00 & NG \\
\hline 10 & \multirow{3}{*}{130} & 15 & 6,00 & 4,90 & NG \\
\hline 11 & & 17 & 6,00 & 5,20 & NG \\
\hline 12 & & 20 & 6,00 & 5,40 & NG \\
\hline 13 & \multirow{3}{*}{140} & 15 & 6,00 & 5,25 & NG \\
\hline 14 & & 17 & 6,00 & 5,60 & NG \\
\hline 15 & & 20 & 6,00 & 6,70 & OK \\
\hline 16 & \multirow{3}{*}{150} & 15 & 6,00 & 5,40 & NG \\
\hline 17 & & 17 & 6,00 & 6,68 & OK \\
\hline 18 & & 20 & 6,00 & 7,80 & OK \\
\hline 19 & \multirow{3}{*}{160} & 15 & 6,00 & 6,10 & OK \\
\hline 20 & & 17 & 6,00 & 7,00 & OK \\
\hline 21 & & 20 & 6,00 & 7,70 & OK \\
\hline 22 & \multirow{3}{*}{170} & 15 & 6,00 & 6,40 & OK \\
\hline 23 & & 17 & 6,00 & 7,20 & OK \\
\hline 24 & & 20 & 6,00 & 8,20 & OK \\
\hline 25 & \multirow{3}{*}{180} & 15 & 6,00 & 7,00 & OK \\
\hline 26 & & 17 & 6,00 & 8,10 & OK \\
\hline 27 & & 20 & 6,00 & 8,70 & OK \\
\hline 28 & \multirow{2}{*}{190} & 15 & 6,00 & 7,30 & OK \\
\hline 29 & & 17 & 6,00 & 8,40 & OK \\
\hline
\end{tabular}

Spesimen pengelasan dengan hasil lulus (OK) akan dilanjutkan ke pengujian analisis foto makro untuk mengetahui ukuran-ukuran hasil pengelasan yang tidak dapat diukur secara manual.

\section{Hasil Inspeksi Analisis Struktur Makro}

Untuk mendapatkan hasil pengelasan yang sesuai, maka dilakukan dengan mencari nilai rata-rata (mean) untuk setiap hasil pengukuran kemudian nilai tersebut digunakan sebagai batas nilai minimum, apabila nilai hasil pengukuran lebih besar dari nilai batas minimum maka pengukuran tersebut dinyatakan lulus (OK) dan juga sebaliknya.

Sampel hasil pengelasan yang tidak memiliki keputusan gagal (NG) atau hasil keputusannya lulus (OK) semua, maka akan ditetapkan sebagai parameter pengelasan yang sesuai atau parameter 
pengelasan yang akan digunakan untuk produksi massal nantinya. Untuk lebih jelasnya dapat dilihat pada Tabel 3 dan 4 di bawah ini:

Nilai pengukuran $\leq$ Nilai Batas Minimum $=$ NG $($ NOT GO $)$

Nilai pengukuran $>$ Nilai Batas Minimum $=$ OK

Tabel 3. Hasil pengujian analisis struktur makro spesimen Pipe Head

\begin{tabular}{|c|c|c|c|c|c|c|c|c|c|c|c|c|c|c|c|c|}
\hline No & No Sampel & Ampere & Voltage & Al & A2 & Bead Width & Throuth & Leg Length & Crown & Hasil A1 & Hasil A2 & $\begin{array}{c}\text { Hasil } \\
\text { Bead Width }\end{array}$ & $\begin{array}{c}\text { Hasil } \\
\text { Throut }\end{array}$ & $\begin{array}{c}\text { Hasil } \\
\text { Leg Length } \\
\end{array}$ & $\begin{array}{c}\text { Hasil } \\
\text { Crown }\end{array}$ & HASIL \\
\hline 1 & 11 & \multirow{2}{*}{130} & 17 & 1,18 & 0,28 & 6,12 & 2,3 & 4 & 0,5 & NG & NG & \begin{tabular}{|l|} 
NG \\
\end{tabular} & NG & \begin{tabular}{|l|} 
NG \\
\end{tabular} & NG & GAGAL \\
\hline 2 & 12 & & 20 & 1,51 & 0,58 & 6,58 & 2,36 & 4,16 & 0,51 & OK & OK & NG & NG & NG & NG & GAGAL \\
\hline 3 & 14 & \multirow{2}{*}{140} & 17 & 1,23 & 0,7 & 6,37 & 2,51 & 4,48 & 0,55 & NG & OK & NG & NG & NG & NG & GAGAL \\
\hline 4 & 15 & & 20 & 1.83 & 0.25 & 7,65 & 2,62 & 4,58 & 0.85 & OK & NG & OK & NG & NG & OK & GAGAL \\
\hline 5 & 16 & \multirow{3}{*}{150} & 15 & 1 & 0,39 & 7,02 & 2,46 & 4,72 & 0,57 & NG & NG & NG & NG & NG & NG & GAGAL \\
\hline 6 & 17 & & 17 & 0,86 & 0,46 & 6,2 & 2,81 & 4,37 & 0,74 & NG & NG & NG & OK & NG & NG & GAGAL \\
\hline 7 & 18 & & 20 & 1,19 & 0,66 & 7,71 & 2,39 & 5,19 & 0,59 & NG & OK & OK & NG & OK & NG & GAGAL \\
\hline 8 & 19 & \multirow{3}{*}{160} & 15 & 1,27 & 0,38 & 6,67 & 3,05 & 4,41 & 0,96 & NG & NG & NG & OK & NG & OK & GAGAL \\
\hline 9 & 20 & & 17 & 1,34 & 0.7 & 6,86 & 2,52 & 4.8 & 0,6 & NG & OK & NG & NG & NG & NG & GAGAL \\
\hline 10 & 21 & & 20 & 1,67 & 0,8 & 8,1 & 2,38 & 5,5 & 0,5 & OK & OK & OK & NG & OK & NG & GAGAL \\
\hline 11 & 22 & \multirow{2}{*}{170} & 15 & 1,05 & 0,57 & 6,98 & 2,8 & 4,68 & 0,77 & NG & OK & NG & OK & NG & NG & GAGAL \\
\hline 12 & 23 & & 17 & 1,86 & 0,51 & 7,8 & 2,63 & 5,07 & 0,96 & OK & NG & OK & NG & OK & OK & GAGAL \\
\hline 13 & 24 & 170 & 20 & 1,77 & 0,57 & 8,7 & 2,76 & 6,03 & 0,98 & OK & OK & OK & OK & OK & OK & LULUS \\
\hline 14 & 25 & \multirow{3}{*}{180} & 15 & 1,07 & 0,67 & 7,48 & 2,66 & 5,19 & 0,85 & NG & OK & OK & OK & OK & OK & GAGAI \\
\hline 15 & 26 & & 17 & 1,08 & 0,55 & 7,43 & 3,16 & 5,54 & 0,93 & NG & OK & OK & OK & OK & OK & GAGAL \\
\hline 16 & 27 & & 20 & 2,44 & 0,35 & 9,03 & 2,72 & 5,29 & 1,18 & OK & NG & OK & OK & OK & OK & GAGAL \\
\hline 17 & 28 & \multirow{2}{*}{190} & 15 & 0,93 & 0,73 & 7,72 & 2,77 & 5,37 & 0,95 & NG & OK & OK & OK & OK & OK & GAGAL \\
\hline \multirow[t]{3}{*}{18} & 29 & & 17 & 1,28 & 0,24 & 8,12 & 2,64 & 5,02 & 1 & NG & NG & OK & OK & OK & OK & GAGAL \\
\hline & & & & & & & & & & & & & & & & \\
\hline & \multicolumn{3}{|c|}{ MEAN / Nilai Batas Minimum } & 1,36 & 0,52 & 7,36 & 2,64 & 4,91 & 0,78 & & & & & & & \\
\hline
\end{tabular}

Dari tabel di atas dapat dilihat bahwa hanya sampel pengujian parameter pengelasan ke-24 yang seluruh hasil pengujiannya dinyatakan lulus (OK), sehingga sampel tersebut dinyatakan sebagai sampel dengan parameter pengelasan yang sesuai untuk pengelasan pipe head. Sampel ke24 adalah sampel pengelasan dengan paramater arus listrik pengelasan 170 ampere dan tegangan listrik pengelasan 20 volt. Hasil pengelasan tersebut dapat dilihat pada Gambar 9 di bawah ini:

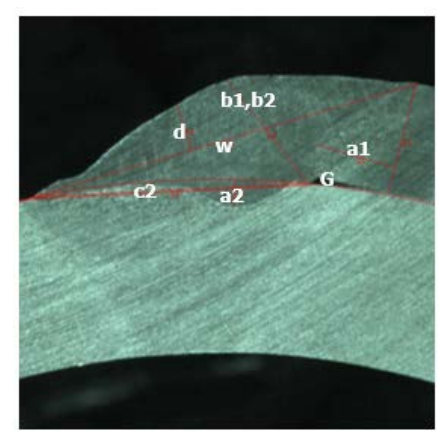

\begin{tabular}{|c|c|c|c|c|c|c|}
\hline $\begin{array}{c}\text { Lebar Bead } \\
\text { Welding } \\
\text { [mml }\end{array}$ & $\begin{array}{l}\text { Penetrasi } \\
\text { Material } 1 \\
\text { (a1) } \\
\text { [mm] }\end{array}$ & $\begin{array}{c}\text { Penetrasi } \\
\text { Material } 2 \\
\text { (a2) } \\
\text { [mm] }\end{array}$ & $\begin{array}{c}\text { Throuth } \\
(\mathrm{b} 1, \mathrm{~b} 2) \\
{[\mathrm{mml}]}\end{array}$ & $\begin{array}{c}\text { Len } \\
\text { Length } \\
\text { (c2) } \\
\text { [mml }\end{array}$ & $\begin{array}{c}\text { Crow } \\
n \\
\text { (d) } \\
{[\mathrm{mm}]}\end{array}$ & Porositas \\
\hline 8,70 & 1,77 & 0,57 & 2,76 & 6,03 & 0,98 & Tidak Ada \\
\hline
\end{tabular}

Gambar 9. Hasil pengelasan spesimen Pipe Head pada Posisi Vertikal (3G) yang sesuai

Tabel 4. Hasil pengujian analisis struktur makro spesimen Pipe Main

\begin{tabular}{|c|c|c|c|c|c|c|c|c|c|c|c|c|c|c|c|c|}
\hline No & No Sampel & Ampere & Voltage & Al & A2 & Bead Width & Throuth & Leg Length & Crown & Hasil A1 & Hasil A2 & \begin{tabular}{|c|} 
Hasil \\
Bead Width \\
\end{tabular} & $\begin{array}{l}\text { Hasil } \\
\text { Throut }\end{array}$ & $\begin{array}{c}\text { Hasil } \\
\text { Leg Length }\end{array}$ & $\begin{array}{l}\text { Hasil } \\
\text { Crown }\end{array}$ & HASIL \\
\hline 1 & 15 & 140 & 20 & 1,61 & 1,16 & 6,89 & 2,34 & 4,35 & 0,67 & OK & OK & NG & NG & \begin{tabular}{|l|} 
NG \\
\end{tabular} & NG & GAGAI \\
\hline 2 & 17 & \multirow{2}{*}{150} & 17 & 1,15 & 1,33 & 6,75 & 2,32 & 4,52 & 0,67 & NG & OK & NG & NG & NG & NG & GAGAI \\
\hline 3 & 18 & & 20 & 2,01 & 0,6 & 7,86 & 2,72 & 4,89 & 0,76 & OK & NG & OK & NG & NG & NG & GAGAI \\
\hline 4 & 19 & \multirow{3}{*}{160} & 15 & 0,96 & 0,24 & 6,22 & 3,08 & 4,28 & 1 & NG & NG & NG & OK & NG & OK & GAGAL \\
\hline 5 & 20 & & 17 & 0,92 & 0,87 & 7,11 & 2,77 & 4,97 & 0,81 & NG & OK & NG & NG & NG & NG & GAGAL \\
\hline 6 & 21 & & 20 & 1,61 & 0,65 & 7,79 & 2,84 & 4,89 & 0,89 & OK & NG & OK & NG & NG & NG & GAGAL \\
\hline 7 & 22 & \multirow{3}{*}{170} & 15 & 0,95 & 0,61 & 6,47 & 3,25 & 4,65 & 0,86 & NG & NG & NG & OK & NG & NG & GAGAL \\
\hline 8 & 23 & & 17 & 1,19 & 0,64 & 7,26 & 3,15 & 5,41 & 0,83 & NG & NG & NG & OK & OK & NG & GAGAL \\
\hline 9 & 24 & & 20 & 1,81 & 0,65 & 8,27 & 2,88 & 5,4 & 0,93 & OK & NG & OK & NG & OK & OK & GAGAL \\
\hline 10 & 25 & \multirow{3}{*}{180} & 15 & 1,07 & 0,7 & 7,12 & 3,05 & 4,98 & 0,83 & NG & OK & NG & OK & NG & NG & GAGAL \\
\hline 11 & 26 & & 17 & 2,21 & 0,89 & 8,29 & 3 & 5,2 & 0,95 & OK & OK & OK & OK & OK & OK & LULUS \\
\hline 12 & 27 & & 20 & 1,86 & 0,3 & 8,79 & 2,96 & 5,69 & 1,13 & OK & NG & OK & OK & OK & OK & GAGAL \\
\hline 13 & 28 & \multirow{2}{*}{190} & 15 & 0,94 & 0,34 & 7,35 & 2,97 & 4,85 & 0,83 & NG & NG & OK & OK & NG & NG & GAGAL \\
\hline \multirow[t]{3}{*}{14} & 29 & & 17 & 1,94 & 0,66 & 8,43 & 3,36 & 5,72 & 1,34 & OK & NG & OK & OK & OK & OK & GAGAL \\
\hline & & & & & & & & & & & & & & & & \\
\hline & \multicolumn{3}{|c|}{ MEAN/ Nilai Batas Minumum } & 1,45 & 0,69 & 7,47 & 2,91 & 4,99 & 0,89 & & & & & & & \\
\hline
\end{tabular}


Dari tabel di atas dapat dilihat bahwa hanya sampel pengujian parameter pengelasan ke-26 yang seluruh hasil pengujiannya dinyatakan lulus (OK), sehingga sampel tersebut dinyatakan sebagai sampel dengan parameter pengelasan yang sesuai untuk pengelasan pipe main. Sampel ke26 adalah sampel pengelasan dengan paramater arus listrik pengelasan 180 ampere dan tegangan listrik pengelasan 17 volt. Hasil pengelasan tersebut dapat dilihat pada Gambar 10 di bawah ini:

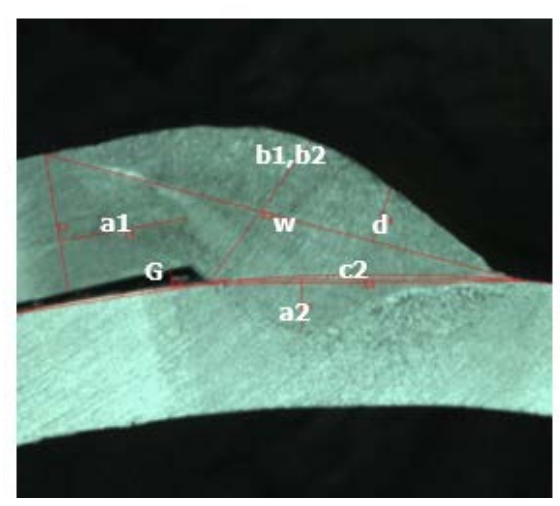

\begin{tabular}{|c|c|c|c|c|c|c|}
\hline $\begin{array}{c}\text { Lebar Bead } \\
\text { Welding } \\
\text { [mml }\end{array}$ & $\begin{array}{c}\text { Penetrasi } \\
\text { Material } 1 \\
\text { (a1) } \\
{[\mathrm{mm}]}\end{array}$ & $\begin{array}{c}\text { Penetrasi } \\
\text { Material } 2 \\
\text { (a2) } \\
\text { [mm] }\end{array}$ & $\begin{array}{c}\text { Throuth } \\
(\mathrm{bl}, \mathrm{b} 2) \\
{[\mathrm{mm}]}\end{array}$ & $\begin{array}{l}\text { Leq } \\
\text { Length } \\
\text { (c2) } \\
\text { [mml] }\end{array}$ & $\begin{array}{c}\text { Crow } \\
n \\
\text { (d) } \\
{[\mathrm{mml}]}\end{array}$ & Porositas \\
\hline 8,29 & 2,21 & 0,89 & 3,00 & 5,20 & 0,95 & Tidlak Ada \\
\hline
\end{tabular}

Gambar 10. Hasil pengelasan spesimen Pipe Main pada

Posisi Horizontal (2G) yang sesuai

\section{SIMPULAN}

Dapat diketahui bahwa parameter pengelasan MIG otomatis yang sesuai untuk pengelasan rangka utama sepeda motor matik bagian depan, dengan melakukan percobaan pengelasan menggunakan parameter pengelasan yang bervariasi, yaitu: arus listrik pengelasan (ampere) mulai dari 100 hingga 190 ampere dengan tegangan listrik pengelasan (voltage) sebesar 15; 17 dan 20 volt untuk setiap arus listrik pengelasan yang digunakan, serta parameter pengelasan yang dibuat tetap, yaitu: travel speed sebesar 0,8 meter/menit; gas flow sebesar 10 liter/menit; sudut torch sebesar $10^{\circ}$; sudut pengelasan sebesar $70^{\circ}$; jarak tip ke benda kerja sebesar $10 \mathrm{~mm}$; polaritas pengelasan DCEP; arah pengelasan maju untuk posisi pengelasan vertikal (3G) dan arah pengelasan mundur untuk posisi pengelasan horizontal (2G), maka didapatkan hasil pengelasan sebagai berikut: 1) Pengelasan dengan posisi pengelasan vertikal (3G) dengan arah pengelasan kebawah (vertical downhill), hasil pengelasan terbaik didapatkan pada saat pengelasan menggunakan arus listrik pengelasan sebesar 170 ampere dan tegangan pengelasan yang digunakan sebesar 20 volt. 2) Pengelasan dengan posisi pengelasan horizontal (2G), hasil pengelasan terbaik didapatkan pada saat pengelasan menggunakan arus listrik pengelasan sebesar 180 ampere dan tegangan pengelasan yang digunakan sebesar 17 volt.

\section{DAFTAR PUSTAKA}

[1]. Helzer, C. and Cary, B, Howard, 2005, Modern Welding Technology Sixth Edition, New Jersey: PEARSON Prenctice Hall.

[2]. Irwan, Yusril, 2013, Proses Pengelasan, Bandung:CV.Habsa Jaya. ISBN 602891365-0.

[3]. Wiryono, Harsono dan Okumura, Toshie, 2004, Teknologi Pengelasan Logam, Jakarta: PT. Pradnya Paramita, ISBN 979-408-175-2.

[4]. “Analisa Struktur Makro”, diakses dari http://himatl.ppns.ac.id/wpcontent/ uploads/2015/ 05/22.png, tanggal 9 Mei 2016.

[5]. "Standar JIS Material STAM 390 G”, diakses dari http://www.totalmateria.com/ materials. $a s p x ? s t=J I S \& g r=2 \& d b=S \& L N=E N$, tanggal 9 Mei 2016.

[6]. "Pengelasan MIG”, diakses dari http://staff.uny.ac.id/sites/default/files/MIG.pdf, tanggal 9 Mei 2016. 